\title{
The Enemy (2007)
}

"Rafael Campo writes tough, questioning, rueful, exquisite, truehearted poems that resist nostalgia while testing the transformative power of beauty. In perfectly wrought poem after poem, he explores the 'honor' of sacrifice and the breadth of human fidelities. The Enemy is surely Campo's best book yet."-ELIZABETH ALEXANDER, Yale University

"Rafael Campo is one of the most significant poets writing in America today. In exploring the complexities of his position-Cuban American, gay, Harvard grad, physician, scrupulous observer of himself, of others, and of the worlds we inhabit-he has produced a richly textured, layered body of work, distinguished for its mastery of, and wrestling with, poetic form, as well as for its courage, compassion, and clarity. Hybrid - a mix of memory and desire, trust and fear, anger and love-his work has always been death-haunted yet he speaks for what is alive and healing in American culture."-ALICIA SUSKIN OSTRIKER, author of No Heaven

“Rafael Campo's The Enemy moves with naturalness, speed, and balance between experiences of domestic love-a couple of gay men, celebrating rites of daily ordinariness-and scenes from a doctor's life. We turn to Campo for frankness, freshness, and the tang of truth, and we are rewarded."-ROSANNA WARREN, author of Departure

"[Campo] writes of music and celebrates the erotic. He has awe for the mysterious and a familiarity with despair, and he catches frequent hints of God's presence. In this book, there are tiresome days in the clinic and patients who are near death but who will not die.... [His] poems show how medicine can best be of service in the absence of cures or quick fixes, and how medical professionals can best be present, mindfully and emotionally, during moments of human suffering." - HEATHER A. BURns, The New England Journal of Medicine 


\section{Landscape with Human Figure (2002)}

"Rafael Campo is an accomplished formalist. I hugely enjoy watching him skitter from sestina to pantoum, sonnet to rhymed couplets, to say nothing of his own nonce forms devised as the situation suggests." —MAXINE KUMIN

"Landscape with Human Figure is a striking achievement. I am moved, as his readers are sure to be, by Campo's wisdom, maturity, depth, heart, and range of experience."-GRACE SCHULMAN

"Campo writes restless, worldly narrative poems, often rhyming, that take-and unapologetically engage - the world as it presents itself. ... [His] insouciant, call-them-as-I-seem-them descriptions . . . are luminous, addressing the ravages of AIDS, particularly, with care and respect."-Publishers Weekly

“Ambitious, elegant poems. .. Campo's clear gaze, generous heart, and great skill combine to create a resonant and often romantic collection of poems, one that locates and celebrates all our shared 'outsider' hearts."-KEVIN RIORDAN, Philadelphia Gay News

"Physician Rafael Campo confirms his status as one of America's most important poets."-Hispanic Outlook

"Campo writes compelling poems ... probing relationships between doctor and patient, between a patient's case 'history' and the cultural mainstream, between an immigrant family and aspirations to study medicine, between sexuality and the restraint of lovers. Not unlike Chekhov, another physician-author, the steady-eyed Campo comes to terms with the darkest of human problems ... by fusing empathy and clinical accuracy. Strengthened by his hands-on knowledge of healing and suffering and kept gentle by bearing his burdens with grace, Campo asserts that, despite 'the harrowed world ... we are together, we are here to stay." - FRAN K ALLEN, Library Journal 


\section{Diva (1999)}

"Extraordinary meditations on illness and the healing power of words."-Lambda Literary Foundation

"Campo writes mordant lyrics of dark love that displace trite expectations of what sonnets or canciones should accomplish. ... [His] work hastens our absorption of what initially seems alien."-JERRY W. WARD JR., The Washington Post Book World

"A virtuoso display. ... Campo is a master of image. ... His poems are revealing and courageous."-JAY A. LIVESON, MD, JAMA: The Journal of the American Medical Association

"Rafael Campo is perhaps our most distinguished physician-poet since William Carlos Williams."-DAVID BERGMAN, The Gay and Lesbian Review Worldwide

"I know of no poet writing today with more courage and compassion than Rafael Campo. Like the practicing physician that he is, Campo writes poems that heal artfully-or honestly face the impossibility of healing. Here we find sonnets for the damned, songs for the dying, the insistence on empathy for a prostitute with AIDS on a Boston street corner. There is the unforgiving squint of a mother rejecting her gay son. Yet there is a soaring lyricism in these poems, epiphany and redemption, a celebration of bloodstained, stubborn life as it bursts forth. The poems of Rafael Campo inspire that sharp breath of recognition. He has all my gratitude and admiration."-MARTín ESPADA, author of Imagine the Angels of Bread

\section{What the Body Told (1996)}

"Rafael Campo is one of the most gifted and accomplished younger poets writing in English. More than that, he is a writer engaged in several of the pivotal struggles/issues of our era, and what he has to say about them is 'news that stays news." - MARILYN HACKER 
"Campo is one of the most attractive, interesting, and-I can think of no better word-valuable poets of his generation. The news he has to tell is the news we need, and his talent, happily, is equal to his message."-RICHARD HOWARD

"Campo's background and concerns-he writes out of his identity and experience as a gay Cuban-American physician-make for a rich field of investigations, and his best work is both passionate and formally accomplished. What the Body Told dives into the difficult, necessary territory of physical love, desire, contagion, illness; such poems are essential to our moment. We need them."-MARK DOTY 
ALternative MEDicine 



\title{
A L T E R N A T IV E
}

\author{
M E D I C I N E
}

\section{RAFAEL C AMPO}

DUKE UNIVERSITY PRESS

Durham and London • 2014 
() 2014 Rafael Campo

All rights reserved

Printed in the United States

of America on acid-free paper $\infty$

Designed by Amy Ruth Buchanan

and typeset in Quadraat.

Library of Congress Cataloging-in-

Publication Data

Campo, Rafael.

Alternative medicine / Rafael Campo.

pages $\mathrm{cm}$

ISBN 978-0-8223-5573-I (cloth : alk. paper)

ISBN 978-0-8223-5587-8 (pbk. : alk. paper)

I. Title.

PS3553.A4883A48 2013

8II'.54-dc23

2013030385 